\title{
Distribution and hydrogeochemical behavior of arsenic-enriched groundwater in the sedimentary aquifers: Comparison between Datong Basin, China and Kushtia District, Bangladesh
}

\author{
M.-E. Huq, C.L. Su, J.X. Li \& R. Liu \\ School of Environmental Studies, China University of Geosciences (Wuhan), Wuhan, Hubei, P.R. China
}

\begin{abstract}
High arsenic (As) groundwater has become a major global concern due to its widespread occurrence. A comparative hydrogeochemical study was performed on the As-enriched groundwater in Datong Basin, China and Kushtia District, Bangladesh. The elevated As concentrations of Datong Basin ranged from 0.31 to $452 \mu \mathrm{g} \mathrm{L}^{-1}$. As enriched groundwater is mainly $\mathrm{Na}-\mathrm{HCO}_{3}$ type water, and characterized by higher $\mathrm{pH}$ value, high $\mathrm{Na}^{+}$, low $\mathrm{Ca}^{2+}, \mathrm{SO}_{4}^{2-}$ and $\mathrm{NO}_{3}^{-}$along with moderate TDS. The release of As in aquifers resulted from the reduction of As-carrying crystalline iron $(\mathrm{Fe})$ oxide/hydroxides and oxidation of organic matter. The aquifers of Kushtia District, Bangladesh are unconsolidated, alluvial in nature, and developed from Holocene floodplain and Pleistocene deposits. High As $\left(6.04-590.7 \mu \mathrm{g} \mathrm{L}^{-1}\right)$ groundwater occurs mainly in shallow aquifers. The $\mathrm{Ca}-\mathrm{HCO}_{3}$ type groundwater is distinguished by circum-neutral $\mathrm{pH}$, medium-high $\mathrm{EC}$, high $\mathrm{HCO}_{3}^{-}$, and low content of $\mathrm{NO}_{3}^{-}, \mathrm{SO}_{4}^{2-}, \mathrm{K}^{+}$and $\mathrm{Cl}^{-}$. The reductive suspension of $\mathrm{MnOOH}$ increased the dissolved As loads and redox responsive elements such as $\mathrm{SO}_{4}^{2-}$ and pyrite oxidation acted as the main mechanisms for As release in groundwater. The weak loading of Fe suggests that the release of $\mathrm{Fe}$ and As was decoupled in sedimentary aquifers of Kushtia District.
\end{abstract}

\section{INTRODUCTION}

High arsenic (As) groundwater is the most crucial natural hazard to public health and the largest environmental hazards in the world (Wang \& Wai, 2004). Among the As polluted regions, India, Bangladesh, and China are mostly affected. Currently, millions of people are still consuming As contaminated water above the WHO recommended value $\left(10 \mu \mathrm{g} \mathrm{L}^{-1}\right)$ for drinking water both in China and Bangladesh (Bibi et al., 2008; Wang \& Deng, 2009). Since last two decades, many studies have been conducted on the causes of As enrichment at Datong Basin, and Bangladesh but the different mechanisms of As release has remain poorly defined. The objectives of this study are (1) to compare the hydrogeochemical characteristics of the elevated As groundwater, and (2) to identify the different mechanisms of As release occurred in the sedimentary aquifers of these two areas.

\section{METHODS}

\subsection{Study area}

Datong Basin, one of the Cenozoic fault basins of the Shanxi rift system that is situated in the north of Shanxi Province, China and Kushtia District is located in the southwest of Bangladesh were selected as the study area.

\subsection{Sampling and hydrogeochemical analysis}

To investigate the hydrogeochemical properties of groundwater, a total of 132 groundwater samples (83 from Datong Basin and 49 from Kushtia District) were collected from tubewells. All of the water samples were filtered through $0.45 \mu \mathrm{m}$ membranes and preserved in $50 \mathrm{ml}$ polyethylene bottles for anion, cations and trace elements analysis. Hydride generation-atomic fluorescence spectrometry (HG-AFS) (Titan AFS 830) inductively coupled plasma atomic emission spectrometry (ICP-AES) and Ion Chromatography (IC) (Metrohm-761 Compact IC) were used to measure total dissolved As, major ions and concentration of trace elements respectively.

\section{RESULTS AND DISCUSSION}

Different mechanisms are responsible for As enrichment in the groundwater of each study area. Factor analysis (FA) was performed on the hydrochemical data to explore the causes of elevated As occurrence in the groundwater of these two study areas. In Datong Basin, China, $F 1$ explains $20 \%$ of total variance including strong positive loadings of $\mathrm{Ca}^{2+}$, $\mathrm{Mg}^{2+}, \mathrm{Na}^{+}, \mathrm{Cl}^{-}, \mathrm{SO}_{4}^{2-}, \mathrm{Fe}, \mathrm{Cu}, \mathrm{Se}, \mathrm{Li}, \mathrm{B}, \mathrm{Sr}$ and $\mathrm{V}$ with the negative loading of $\mathrm{EC}$, while others show weak loading (Table 1). The positive loading of $\mathrm{Cl}^{-}$ can be derived due to evaporation and may increase along the flow path from recharge to discharge area. $F 2$ accounts for $19.79 \%$ of total variance, with strong positive loading of $\mathrm{pH}, \mathrm{B}$, and $\mathrm{Ba}$ and negative loading of $\mathrm{Ca}^{2+}$. In Datong Basin, high As mostly occurs with the $\mathrm{pH}$ value exceeding 7.95. F3 covers $16.28 \%$ of the total variance. $\mathrm{Ba}$ is an indicator for a marine groundwater environment, so this factor may be associated with a marine groundwater environment due 
Table 1. Factor loadings of different chemical parameters of groundwater from the two study sites.

\begin{tabular}{|c|c|c|c|c|c|c|}
\hline \multirow[b]{2}{*}{ Components } & \multicolumn{3}{|c|}{ Datong Basin, China } & \multicolumn{3}{|c|}{ Kushtia, Bangladesh } \\
\hline & $F 1$ & $F 2$ & $F 3$ & $F 1$ & $F 2$ & $F 3$ \\
\hline As & -.311 & .318 & -.141 & -.055 & .146 & .108 \\
\hline $\mathrm{Ca}^{2+}$ & .602 & -.659 & .245 & .161 & .075 & .884 \\
\hline $\mathrm{K}^{+}$ & .441 & -.225 & .234 & .680 & .085 & -.049 \\
\hline $\mathrm{Mg}^{2+}$ & .760 & -.468 & -.097 & .507 & .548 & .253 \\
\hline $\mathrm{Na}^{+}$ & .798 & -.077 & -.521 & .817 & -.138 & .217 \\
\hline $\mathrm{Cl}^{-}$ & .798 & -.077 & -.521 & .888 & .197 & .105 \\
\hline $\mathrm{NO}_{3}^{-}$ & .407 & -.149 & -.049 & -.004 & .048 & -.104 \\
\hline $\mathrm{SO}_{4}^{2-}$ & .806 & -.365 & -.271 & .848 & .048 & -.002 \\
\hline $\mathrm{pH}^{4}$ & -.308 & .504 & -.484 & -.017 & -.557 & -.049 \\
\hline EC & -.590 & .103 & .243 & .347 & .675 & .215 \\
\hline $\mathrm{T}$ & -.148 & .112 & .024 & .092 & .181 & 217 \\
\hline Depth & -.480 & .147 & .032 & -.167 & -.090 & -.188 \\
\hline $\mathrm{HCO}_{3}^{-}$ & .477 & .409 & -.593 & .193 & .213 & .806 \\
\hline TDS & .370 & -.254 & -.382 & .487 & .207 & .683 \\
\hline $\mathrm{Cr}$ & .026 & -.025 & .250 & .008 & -.185 & .050 \\
\hline $\mathrm{Mn}$ & .481 & .264 & .343 & -.169 & -.129 & .783 \\
\hline $\mathrm{Fe}$ & .751 & -.276 & .407 & -.197 & .205 & -.191 \\
\hline $\mathrm{Ni}$ & .370 & .117 & .398 & -.008 & -.010 & .039 \\
\hline $\mathrm{Cu}$ & .822 & .308 & .133 & -.203 & -.097 & .012 \\
\hline $\mathrm{Pb}$ & .467 & .365 & -.245 & .042 & -.785 & -.122 \\
\hline $\mathrm{Se}$ & .710 & .425 & .241 & -.321 & .100 & .304 \\
\hline $\mathrm{Li}$ & .876 & .182 & .159 & -.010 & -.778 & .063 \\
\hline B & .684 & .619 & -.148 & .362 & .580 & .075 \\
\hline $\mathrm{Ba}$ & .282 & .612 & .570 & .552 & .018 & .269 \\
\hline $\mathrm{Sr}$ & .851 & -.092 & .258 & .415 & .307 & .575 \\
\hline V & .641 & .416 & .121 & -.015 & -.736 & -.104 \\
\hline Var & 20.00 & 19.79 & 16.28 & 16.06 & 13.8 & 12.9 \\
\hline Cumulative (\%) & 20.00 & 39.79 & 56.07 & 16.06 & 29.9 & 42.8 \\
\hline
\end{tabular}

to the strong positive loading of $\mathrm{Ba}(0.57)$. In Kushtia District, Bangladesh in $F 1$ strong loading of $\mathrm{Mg}^{2+}$ suggests that it may come from the weathering of silicate or carbonate suspension. The excessive alkalinity may serve as an extra source of $\mathrm{Mg}^{2+}$ and the balance of $\mathrm{Cl}^{-}$and $\mathrm{SO}_{4}^{2-}$. In $F 2$, the strong negative loading of $\mathrm{pH}$ suggests that the $\mathrm{pH}$-dependent reactions are not the predominant features of As enrichment in groundwater. $F 3$ shows a positive loading of $\mathrm{Ca}^{2+}$ that is favorable to the development of the alkali-type soil. Regular and long-term irrigation with $\mathrm{Ca}^{2+}$ enriched water in this area makes the soil plastic as well as humid in the wet season and form clod soil crust in the dry season. $\mathrm{HCO}_{3}^{-}$also shows a positive strong loading indicating three main weathering factors (evaporation, silicate, and carbonate) which increase the As concentration (Table 1).

The negative loading of $\mathrm{HCO}_{3}^{-}$in Datong Basin, indicates that the alkaline environment is associated with the As mobilization (Table 1 and Figure 1a). The comparison of $\mathrm{HCO}_{3}^{-}$and dissolved $\mathrm{Fe}$ suggests that Fe reduction plays a vital role in As release (Figure 1c). $\mathrm{HCO}_{3}^{-}$and $\mathrm{SO}_{4}^{2-}$ are considered to induce As desorption from the Fe mineral shells, and their interactions in the present study reveal that the reactions of redox are the major controlling mechanisms to release As in aquifer system.

The weak loading of Fe (Table 1) of Kushtia District, Bangladesh may be ascribed to the re-precipitation of suspended $\mathrm{Fe}$, suggesting that the release of $\mathrm{Fe}$ and As is decoupled or influenced by other geochemical
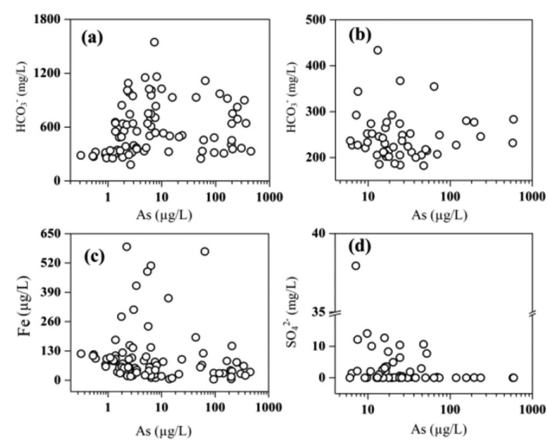

Figure 1. Correlation plots of As with (a) $\mathrm{HCO}_{3}^{-}$for Datong Basin (b) $\mathrm{HCO}_{3}^{-}$for Kushtia (c) Fe for Datong Basin and (d) $\mathrm{SO}_{4}^{2-}$ for Kushtia.

mechanisms (Radloff et al., 2007). The strong positive loading of Mn (Table 1) indicates that the As is predominantly released with the bacterial reductive suspension of Mn oxy-hydroxides. The influence of $\mathrm{HCO}_{3}^{-}$might dominate the As release of the aquifers of Kushtia District in reduction dissolution (Figure 1b). The significant loading of $\mathrm{SO}_{4}^{2-}$ demonstrates that the pyrite oxidation is the key mechanism to As discharge in groundwater (Figure 1d).

\section{CONCLUSIONS}

The association of As and Fe indicates that the ironbearing minerals might be the key carrier of elevated As in aquifers. High alkaline situation, As release from sediments with high $\mathrm{pH}$ environment, and As enrichment under reducing condition are the responsible factors that control and mobilize As in groundwater from sedimentary aquifers of Datong Basin China.In Kushtia district high As mainly occurred in the shallow aquifer indicating that the shallow parts are recharged/infiltrated by the surface water supply. Low concentrations of $\mathrm{NO}_{3}^{-}$and $\mathrm{SO}_{4}^{2-}$ reveal an absolute reducing situation. The high concentration of $\mathrm{HCO}_{3}^{-}$ maybe related to microbial mediated $\mathrm{Fe}$ (III) reduction of organic matter, which creates the reducing condition and releases As in the aquifers. The strong positive loading of Mn suggests that the suspension of $\mathrm{MnOOH}$ might be responsible for dissolved As loads.

\section{REFERENCES}

Bibi, M.H., Ahmed, F. \& Ishiga, H. 2008. Geochemical study of arsenic concentrations in groundwater of the Meghna River Delta, Bangladesh. J. Geochem. Explor. 97: 43-58.

Radloff, K.A., Cheng, Z.Q., Rahman, M.W., Ahmed, K.M., Mailloux, B.J., Juhl, A.R., Schlosser, P. \& Van Geen, A. 2007. Mobilization of arsenic during one-year incubations of grey aquifer sands from Araihazar, Bangladesh. Environ. Sci. Technol. 41: 3639-3645.

Wang, J.S. \& Wai, C.M. 2004. Arsenic in drinking water-a global environmental problem. J. Chem. Educ. 81: 207.

Wang, Y.X. \& Deng, Y.M. 2009. Environmental geochemistry of high-arsenic aquifer systems. Heavy Metal in the Environment. 